Махінчук Наталія Валеріївна аспірантка кафедри публічного управління та публічної служби, Національна академія державного управління при Президентові України, вул. Приозерна, 12-88, м. Київ, 04211, тел.: (095) 312-98-44, e-mail: natalia.makhinchuk@gmail.com, https://orcid.org/0000-0002-9048-0655

\title{
ДЕРЖАВНО-ПРИВАТНЕ ПАРТНЕРСТВО ЯК ІНСТРУМЕНТ ІННОВАЦІЙНОГО РОЗВИТКУ СТОМАТОЛОГІЧНОЇ ДОПОМОГИ НАСЕЛЕННЮ В УКРАЇНІ
}

Анотація. У статті обгрунтовано актуальність розвитку стоматологічної допомоги населенню (СДН) в Україні на засадах державно-приватного партнерства (ДПП). Проаналізовано теоретичні підходи до визначення сутності поняття “державно-приватне партнерство”, а також узагальнено мету та основні ознаки ДПП. Відзначено, що ДПП досить широко використовується у сфері охорони здоров'я, проте має свої специфічні особливості. При цьому одним із складників охорони здоров'я в Україні визначено стоматологічну допомогу населенню, місія якої - збереження та відновлення стоматологічного здоров’я населення та підвищення якості його життя. 3'ясовано основні проблеми в організації СДН та зроблено висновок про необхідність іiі реформування й розробки нової конкурентоспроможної стратегії розвитку з урахуванням нових суспільних викликів (у т.ч. й поширення гострої респіраторної хвороби COVID19). 3 цією метою у сфері СДН запропоновано запровадження нових організаційно-правових форм господарювання, серед яких чільна увага приділена засадам ДПП. Уточнено переваги та найбільш перспективні форми (концесійний договір та спільна діяльність) реалізації ДПП у сфері СДН. Особливу увагу акцентовано на такому напрямку інноваційного розвитку СДН як створення стоматологічних центрів у складі університетських клінік на засадах ДПП, що передбачає ефективну взаємодію медичної науки, освіти та стоматологічної практики на базі стратегічного альянсу органів влади, університетських клінік та приватних інвесторів. Узагальнено передову практику розвинених країн світу в контексті використання засад ДПП як ефективного інструменту вирішення ряду важливих соціально-економічних завдань у сфері СДН. Зроблено висновок, що ДПП може стати ефективним інструментом для впровадження у сферу СДН інноваційних практик лікування, навчання кадрів, технологічного оснащення клінік, поліпшення якості надання медичної допомоги та ін. 
Ключові слова: державне регулювання, державно-приватне партнерство, концесійний договір, охорона здоров'я, спільна діяльність, стоматологічна допомога населенню,

Makhinchuk Natalia Valeriyivna Ph. D candidate of the Department of Public Administration and Public Service, National Academy of Public Administration under the President of Ukraine, Pryozerna St., 12-88, Kyiv, 04211, tel.: (095) 312-98-44, e-mail: natalia.makhinchuk@gmail.com, https://orcid.org/0000-0002-9048-0655

\section{PUBLIC-PRIVATE PARTNERSHIP AS A TOOL OF INNOVATIVE DEVELOPMENT OF DENTAL CARE FOR THE POPULATION IN UKRAINE}

Abstract. The article substantiates the relevance of the development of dental care for the population (DCP) in Ukraine on the basis of public-private partnership (PPP). Theoretical approaches to defining the essence of the concept of "public-private partnership" are analyzed, as well as the purpose and main features of PPP are generalized. It is noted that PPP is widely used in the field of health care, but has its own specific features. At the same time, one of the components of health care in Ukraine is dental care, the mission of which is to preserve and restore the dental health of the population and improve the quality of life. The main problems in the organization of DCP were clarified and the conclusion was made about the need to reform it and develop a new competitive development strategy taking into account new societal challenges (including the spread of acute respiratory disease COVID-19). To this end, in the field of DCP proposed the introduction of new organizational and legal forms of management, among which the main attention is paid to the principles of PPP. The advantages and the most perspective forms (concession agreement and joint activity) of PPP implementation in the field of DCP are substantiated. Particular attention is paid to such an area of innovative development of DCP as the creation of dental centers within university clinics on the basis of PPP, which provides effective interaction of medical science, education and dental practice based on a strategic alliance of government, university clinics and private investors. The best practices of the developed countries of the world in the context of using the principles of PPP as an effective tool for solving a number of important socio-economic problems in the field of DCP are summarized. It is concluded that PPP can become an effective tool for the introduction of innovative treatment practices, training, technological equipment of clinics, improving the quality of medical care, etc.

Keywords: state regulation, public-private partnership, concession agreement, health care, joint activities, dental care for the population. 
Постановка проблеми. На сьогодні медична стоматологічна допомога населенню (СДН) в Україні - один із наймасовіших видів медичної допомоги, що розвивається надзвичайно динамічно в конкурентному середовищі медичних послуг. За кількістю лікарів і відвідувань пацієнтів стоматологія займає друге місце серед усіх медичних спеціальностей [1].

Важливо зауважити, що забезпечення стоматологічного здоров'я населення за останні роки постало надзвичайно актуальною проблемою, яка за своїми масштабами та наслідками вже виходить за рамки суто галузевої, тобто медичної проблеми. Її розв’язання потребує дедалі активного втручання не тільки органів галузевого управління, тобто Міністерства охорони здоров'я (МО3) України, але й органів державної виконавчої влади, органів місцевого самоврядування (OMC), представників наукової медичної спільноти (та суміжних галузей), власне лікарівстоматологів та ін.

При цьому, на наше переконання, основою сучасної соціальної парадигми в цій сфері має бути розуміння того, що стоматологічна допомога населенню є не лише зобов'язанням держави перед суспільством щодо забезпечення доступності стоматологічних послуг, але й перспективним видом економічної діяльності. Саме тому профілактика стоматологічних захворювань та якісна стоматологічна допомога залишаються окремим соціальним пріоритетом державної політики у сфері охорони здоров'я, який передбачає одночасну трансформацію стоматологічної діяльності із соціально-витратної в соціально-інвестиційну. Все це потребує формування інноваційної траєкторії розвитку системи СДН, в реалізації якої вагома роль відводиться використанню як дієвих механізмів державного регулювання, так і пошуку нових стратегічних управлінських рішень в контексті реформування сфери СДН (у т.ч. й в умовах поширення пандемії COVID-19) за рахунок більш тісної взаємодії держави і приватного сектору, а саме державно-приватного партнерства (ДПП). Адже прогресивний досвід розвинених країн світу свідчить, що партнерство держави 3 організаціями приватного сектора може забезпечити стоматологічні заклади новими джерелами фінансування, висококваліфікованими кадрами, сучасними високими технологіями та ін. [2].

Аналіз останніх досліджень i публікацій. Зауважимо, що вітчизняні вчені у своїх публікаціях приділяють чільну увагу питанням імплементації принципів та інструментів ДПП у практику управління закладами охорони здоров'я. Зокрема, різні аспекти розвитку сфери охорони здоров'я та іiі державного регулювання в Україні стали наріжним каменем наукових досліджень М. Білинської, О. Гаврилюка, Т. Грузєвої, Д. Карамишева, Н. Кризиної, I. Петрової, Я. Радиш, Ю. Ридзеля, Н. Чалої та ін. При цьому особливості застосування ДПП у сфері охорони здоров’я досліджували: Т. Алексєєва, 
В. Варнавський, Н. Гойда, Т. Камінська, С. Колесніков, Д. Турчак, Ю. Шевчук, I. Трикоз, К. Павлюк, та ін.

У свою чергу, теоретичні положення щодо формування та розвитку системи СДН в Україні наразі залишаються ще малодослідженими. Хоча окремі аспекти державного регулювання системи СДН (у т.ч. й з використанням засад ДПП) висвітлюються у працях І. Бедрик, М. Голубчикова, Л. Литвинової, О. Мельниченка, О. Павленко, О. Савчука, В. Чопчика, В. Шевцова та ін.

Незважаючи на наявні наукові розробки з досліджуваної проблематики, в сучасному науковому вітчизняному дискурсі ще не набули цілісного відображення теоретичні аспекти взаємної узгодженості соціально-економічних інтересів суб’єктів державного регулювання СДН та залучення інструментарію ДПП до інноваційного розвитку цієї сфери.

Мета статті - проаналізувати сутність ДПП як інструменту інноваційного розвитку стоматологічної допомоги населенню та виявити переваги й перспективи його використання у вітчизняній стоматологічній практиці.

Виклад основного матеріалу. Упродовж останніх років питання партнерської взаємодії держави й приватного сектору набуває особливої актуальності. У даному контексті доцільно зацитувати всесвітньо відомого американського теоретика менеджменту П. Друкера, який вважає, що “...сучасна суверенна унітарна держава замінюється новим плюралізмом - плюралізмом функції, а не лише політикою влади - за тією причиною, що вона більше не в змозі задовольняти потреби суспільства в цілому і виконувати основні завдання місцевих громад. Сьогодні перед нами стоїть дуже серйозне завдання - домогтися плюралізму автономних і заснованих на знаннях організацій, який буде сприяти як досягненню ними економічної ефективності, так і політичній і соціальній єдності суспільства” [3]. Тобто ми солідарні з думкою В. Чопчика, який зауважує, що “характер сучасного державного управління полягає в тому, щоб не надавати громадські послуги державними організаціями безпосередньо, а організовувати цей процес, мобілізуючи потенціали і ресурси громади” [4].

Загалом термін "державно-приватне партнерство" (3 англ. "public-private partnership" (РPР)) широко використовується і в зарубіжній, і у вітчизняній теорії та практиці. Так, у Великобританії для позначення партнерської взаємодії держави та приватного сектору використовується термін "приватна фінансова ініціатива" (PFI), у США, Канаді й Австралії - “публічно-приватне партнерство” (P3 або Р-P partnership), у Франції - “контракт про державно-приватне партнерство” або “співтовариство змішаної економіки” (SEM). Щодо країн СНД, то термін "public-private partnership" перекладають як “державно-приватне партнерство” або “публічно-приватне партнерство”. Це пов'язано з тим, що значення слова "Public" в більшості зарубіжних країн має більш широке значення ніж “державний”. Слово "Public" включає в себе сукупність центральних (муніципальних) органів влади та інших органів/установ (некомерційних організацій, громадських інститутів) [5, с. 89]. 
У наукових дослідженнях термін “державно-приватне партнерство” часто використовують у різних варіаціях. Так, у Практичному керівництві ООН ДПП визначається як "забезпечення фінансування, планування, реалізації та експлуатації об’ єктів, виробництв та надання послуг державного сектора” [6]. У “Зеленій книзі про державно-приватне партнерство та місцеве законодавство про державні контракти i концесіі” для країн СС ДПП визначається як “форма співпраці між органами державної влади та бізнесом, основною метою якої $\epsilon$ забезпечення фінансування, спорудження, реконструкції, управління та утримання об'єктів інфраструктури або надання послуг" [7].

Загалом у зарубіжних країнах партнерську взаємодію держави та бізнесу розглядають як альтернативу приватизації, оскільки ДПП дає можливість державним органам влади залучати кошти приватного сектора без втрати контролю над державними об’єктами [8, с. 20].

Згідно ст. 1 Закону України “Про державно-приватне партнерство”, ДПП - це “співробітництво між державою Україна, Автономною Республікою Крим, територіальними громадами в особі відповідних державних органів та органів місцевого самоврядування (державними партнерами) та юридичними особами, крім державних та комунальних підприємств, або фізичними особами - підприємцями (приватними партнерами), що здійснюється на основі договору в порядку, встановленому Законом та ін. законодавчими актами, та відповідає ознакам державноприватного партнерства, визначеним цим Законом” [9].

У свою чергу, Т. Сугак визначає, що "мета партнерства полягає в поєднанні найкращих сторін державного i приватного секторів для взаємної вигоди, a різноманіття видів, форм і сфер застосування ДПП роблять його універсальним механізмом для виконання цілої низки довгострокових завдань - від створення i розвитку інфраструктури до розроблення та адаптації нових перспективних технологій” [10].

Узагальнений підхід до інтерпретації сутності ДПП візуалізуємо на рис. 1.

\begin{tabular}{|c|}
\hline ДЕРЖАВНО-ПРИВАТНЕ ПАРТНЕРСТВО: \\
\hline залучення приватного партнера державними органами та ОМС \\
\hline 3 метою проєктування, фінансування, будівництва, реконструкції, \\
\hline модернізації, обслуговування, експлуатації \\
\hline об’'сктів державної або комунальної власності \\
\hline на умовах розподілу ризиків, прибутку та відповідальності \\
\hline у формі договору (концесії, спільної діяльності тощо) \\
\hline
\end{tabular}

Pис. 1. Інтерпретація сутності державно-приватного партнерства [узагальнено автором на основі [11, с. 162]] 
Як правило, серед основними ознак ДПП визначають такі:

1) головними сторонами ДПП виступають держава (може бути представлена органами центральної, регіональної та місцевої виконавчої влади, залежно від масштабів проекту) і приватний бізнес (представлений одним або декількома приватними економічними агентами). У певних випадках, до участі в підготовці та реалізації проєктів ДПП можуть бути залучені треті особи: науковці, експерти, кредитори, постачальники, аудитори та ін.;

2) взаємодія сторін закріплюється на офіційній, юридичній основі та носить рівноправний характер;

3) ДПП має чітко виражену публічну, суспільну спрямованість;

4) у процесі реалізації ДПП відбувається консолідація ресурсів і вкладів, розподіл ризиків, досягнутих результатів між учасниками;

5) протягом усього терміну дії договору цільове призначення та форма власності об'єктів залишаються незмінними;

6) дія договору ДПП має тривалий характер (від 5 до 50 років).

Відзначимо, що ДПП на сьогодні досить широко використовується у сфері охорони здоров’я, де має свої специфічні особливості.

Так, ДПП у сфері охорони здоров'я - це передусім об'єднання різних пріоритетів. Як відомо, ст. 3 Конституції України визначає життя і здоров’я людини найвищою соціальною цінністю. Згідно ж зі статтею 42 ГКУ, підприємництво - це самостійна, ініціативна, систематична господарська діяльність, яка здійснюється суб’єктами господарювання (підприємцями) з метою досягнення економічних і соціальних результатів та одержання прибутку. Звідси робимо висновок, що для держави пріоритетною метою охорони здоров'я $\epsilon$ збереження здоров'я іiі громадян, а для суб'єктів підприємництва - отримання прибутку [12]. У результаті виграє й суспільство, яке отримує більш якісні медичні послуги.

Окрім того, до специфічних особливостей проєктів ДПП у сфері охорони здоров'я зараховують: заборону скорочення мережі медичних закладів державного та комунального характеру (передавання відповідних об'єктів приватним партнерам не має призвести до втрати медичними закладами здатності надавати медичні послуги); особливу структуру суб'єктів ДПП, оскільки державний партнер має бути представлений або Міністерством охорони здоров’я України (для тих об’єктів публічної власності, які перебувають під його управлінням), або місцевою владою (для об'єктів комунальної власності); необхідну збалансованість соціальної та бізнесової сторони проєкту (повернення вкладених коштів приватних партнерів відбувається, зазвичай, через платні послуги чи виплати 3 національних українських служб охорони здоров'я); конституційні обмеження щодо платності послуг у державних і комунальних закладах охорони здоров’я, 
вичерпність переліку платних послуг, обмежений перелік послуг, що сплачується Національною службою здоров'я України (НСЗУ), які надаються в державних i комунальних закладах охорони здоров’я та вищих медичних навчальних закладах [13].

Одним із складників охорони здоров’я в Україні є стоматологічна допомога населенню (СДН), основна місія якої - збереження та відновлення стоматологічного здоров’я населення та підвищення якості його життя.

Стоматологічна допомога населенню - це комплекс заходів, які проводять на підставі локальних та уніфікованих протоколів, щодо проведення оцінки, діагностики, профілактики та лікування (хірургічних та не хірургічних) захворювань порожнини рота, щелепово-лицьової області та суміжних i пов’язаних 3 ними впливів на організм людини, 3 метою задоволення потреб людини у підтриманні та відновленні ії стоматологічного здоров'я [14].

При цьому загалом систему СДН доцільно розглядати у складі сфери охорони здоров'я як одну з підсистем соціальної політики суспільства, що взаємопов'язана з багатьма іншими підсистемами та інститутами соціуму. Тобто система СДН - відносно самостійна цілісна багаторівнева структурована сукупність взаємопов'язаних елементів (підсистема власне надання СДН та підсистема менеджменту надання СДН (управління персоналом; атестація, ліцензування, акредитація, сертифікація в стоматологічній діяльності; ціноутворення у сфері СДН; управління у сфері виробництва (поставок) продукції стоматологічного призначення та ін.)), що знаходяться у відносинах координації, ієрархії, субординації, мають свої внутрішні і зовнішні функції, спрямовані на розробку й реалізацію заходів щодо якісного задоволення потреб людини у підтриманні та відновленні їі стоматологічного здоров’я.

Як відомо, Україна успадкувала систему СДН, як і більшість галузей економіки та соціальної політики, від колишнього СРСР. У цій моделі вся система була державною власністю та орієнтувалася на утримання лікарень iз фрагментованим управлінням та надання медичної допомоги, зосередженої на лікуванні гострих випадків при мінімальній профілактиці. Ця система не була зорієнтована на задоволення потреб населення та виявилася нездатною реагувати на сучасні виклики. Вона була сформована у тоталітарній державі, в якій права i здоров’я громадян не були реальним пріоритетом. СРСР також породив міф про “безкоштовну медицину” [15].

Отже, тривалий період державна система стоматологічної допомоги в Україні спиралась на командно-адміністративну модель управління, що є застарілою й неефективною в умовах сьогодення.

Прийняття у 2017 року ВРУ рішення про початок медичної реформи загалом (Закон України "Про державні фінансові гарантії медичного 
обслуговування населення" [16]) визначило новий етап розвитку сфери охорони здоров’я (у т.ч. й системи СДН).

Сучасна вітчизняна система СДН має свої особливості, а саме має чітко виражену медичну, біологічну, організаційно-економічну й публічноуправлінську специфіку. Тому вона фактично, вже функціонує як окрема підгалузь охорони здоров’я.

Стоматологічна допомога, як й інші види медичної допомоги, надається в закладах охорони здоров'я різних форм власності - державних, комунальних, приватних чи заснованих на змішаній формі власності, як у самостійних, так і в структурних підрозділах багатопрофільних закладів. У результаті на сьогодні в Україні працюють такі типи стоматологічних медичних закладів: стоматологічні поліклініки; стоматологічні відділення при лікувально-профілактичних закладах загального профілю; стоматологічні кабінети, розміщені на базі інших установ; самостійні стоматологічні кабінети і центри.

Водночас важливо констатувати, що в Україні всі лікарі стоматологічного профілю віднесені до вторинного рівня медичної допомоги, хоча реальна більшість із них надає первинну стоматологічну допомогу [17]. Тобто наразі в Україні, це питання законодавчо не врегульоване, адже в системі СДН маємо певну колізію: де-юре - стоматологія визнана однією 3 лікарських спеціальностей; де-факто - галузь практично не фінансується, і місцеві органи самоврядування на власний розсуд вирішують, як саме мають виживати комунальні стоматологічні заклади - кого фінансувати, кого переводити на госпрозрахунок, а кого й ліквідувати взагалі. Хоча в більшості європейських країн стоматологічна допомога виділена в окремий вид медичної допомоги, яка надається на всіх рівнях. Відповідно 80\%-85\% лікарів стоматологічного профілю є лікарями-стоматологами загальної практики [18, с. 110].

Загалом можемо стверджувати, що система СДН в Україні перебуває в стані глибокої кризи і стагнації, стоматологічна допомога комерціалізована, вона: не відповідає потребам населення; має недостатній рівень фінансування державною та місцевими органами влади, слабке матеріально-технічне забезпечення та значний знос стоматологічного обладнання, незадовільні умови праці лікарівстоматологів; демонструє недостатню конкурентоздатність, порівняно 3 приватними стоматологічними клініками; має невисокий рівень використання інноваційних технологій у щоденній практиці; характеризується, 3 одного боку, низькою культурою медичного обслуговування, a, 3 іншого, - низькою стоматологічною культурою населення; має низький рівень оплати праці та відсутність економічної мотивації у медичного персоналу та ін. Окрім того в системі СДН залишаються відсутніми: гарантований державою рівень надання безоплатної СДН; науково 
обгрунтований перелік інструментарію та витратних матеріалів для СДН; профілактична спрямованість у діяльності стоматологічних поліклінік; виражена мотивація підтримувати стоматологічне здоров'я та ін.

У свою чергу, виявлені недоліки в організації системи стоматологічної допомоги обумовлюють необхідність іiі термінового реформування та розробки нової конкурентоспроможної стратегії розвитку системи СДН з урахуванням нових викликів, пов'язаних із поширенням гострої респіраторної хвороби COVID19, спричиненої коронавірусом SARSCoV-2. 3 цією метою в системі СДН України розпочинається запровадження нових організаційно-правових форм господарювання, а саме все більш активно починають використовувати механізми ДПП.

На нашу думку, мета ДПП у сфері СДН полягає в підвищенні якості стоматологічних послуг, забезпеченні високої ефективності бюджетного фінансування та функціонування за рахунок залучення практики приватних партнерів тощо. Об'єднання фінансових ресурсів державного i приватного секторів у сфері СДН дозволить ефективніше вирішувати соціальні завдання. Загалом від об'єднання у формі ДПП виграють і бізнес, і держава, і персонал медичного закладу, і головне - пацієнт. Зрештою, це сприятиме підвищенню якості життя населення і посиленню конкурентоздатності.

Основа успішності об’єднання фінансових ресурсів у концепції ДПП у сфері СДН полягає в тому, що і держава, і приватний сектор мають свою специфіку діяльності і свої переваги, при об’єднанні яких формується ця кооперація і створюється ефект синергії. 3'являється можливість більш ефективно працювати i досягати кращих результатів щодо надання доступної та якісної СДН. Важливо зауважити, що синергетичний ефект співпраці держави та приватного партнеру у сфері СДН має певні складнощі, але натомість формує низку переваг для кожного учасника цього процесу (рис. 2).

На наше переконання, найбільш перспективними формами ДПП у сфері

\section{СДН в Україні можна вважати:}

1) концесійний договір ${ }^{1}$ на базі існуючого центру надання медичних послуг. Сторонами договору в такому випадку виступають приватний партнер, місцева влада (представницький орган громади - рада) і медичний заклад

\footnotetext{
${ }^{1}$ Концесійний договір - це договір, відповідно до якого уповноважений орган виконавчої влади чи орган місцевого самоврядування (концесієдавець) надає на платній та строковій основі суб'єктові підприємницької діяльності (концесіонеру) право створити (побудувати) об'єкт концесії чи суттєво його поліпшити та (або) здійснювати його управління (експлуатацію) відповідно до цього Закону з метою задоволення громадських потреб [19].
} 


\begin{tabular}{|c|c|c|}
\hline Для державного партнера & & $\begin{array}{c}\text { Цля приватного партнера та } \\
\text { інвесторив }\end{array}$ \\
\hline $\begin{array}{l}\text { - формування сприятливого } \\
\text { конкурентного середовища у сфері СДН; } \\
\text { - активізація інвестиційної та } \\
\text { інноваційної діяльності у сфері СДН; } \\
\text { - ефективне управління майном; } \\
\text { - створення рівних умов для } \\
\text { стоматологічних установ різних } \\
\text { форм власності; } \\
\text { - оптимізація витрат на надання послуг } \\
\text { та економія фінансових ресурсів; } \\
\text { - використання прогресивного } \\
\text { досвіду приватних стоматологічних } \\
\text { установ; } \\
\text { - підвищення ефективності } \\
\text { інфраструктури у сфері СДН та ін. }\end{array}$ & $\begin{array}{l}\mathbf{E} \\
\mathbf{B} \\
\mathbf{A}\end{array}$ & $\begin{array}{l}\text { - доступ до інноваційних } \\
\text { напрямів/методик діяльності; } \\
\text { - доходи, які отримує державний } \\
\text { партнер, можна інвестувати в } \\
\text { придбання нового медичного } \\
\text { (стоматологічного) обладнання; } \\
\text { - спрощення роботи з дозвільними } \\
\text { структурами; } \\
- \text { додаткові гарантії повернення } \\
\text { інвестицій; } \\
- \text { можливість участі у державних і } \\
\text { міжнародних програмах фінансування; } \\
\text { - отримання кредитів під державні } \\
\text { гарантії та ін. }\end{array}$ \\
\hline Для медичного персоналу & $\Gamma$ & Для пачієнтів \\
\hline $\begin{array}{l}\text { - кращі можливості для реалізації } \\
\text { дослідницьких проєктів і реалізації } \\
\text { сучасних технологій лікування } \\
\text { тяжких стоматологічних захворювань; } \\
\text { - можливість підвищення заробітної } \\
\text { плати персоналу та ін. }\end{array}$ & И & $\begin{array}{l}\text { - отримання якісного і швидкого } \\
\text { стоматологічного обслуговування; } \\
\text { - можливість користуватися } \\
\text { безкоштовними якісними послугами } \\
\text { стоматологічної установи та ін. }\end{array}$ \\
\hline
\end{tabular}

Конструктивний діалог між державним і приватним сектором; розподіл ризиків при реалізації проектів у сфері СДН; позитивний імідж у суспільстві та ін.

\section{ДЕРЖАВНО-ПРИВАТНЕ ПАРТНЕРСТВО У СФЕРІ СДН}

\section{Pис. 2. Переваги ДПП у сфері стоматологічної допомоги населенню [узагальнено та систематизовано автором]}

(сьогодні це переважно комунальні некомерційні підприємства). До переваг цієї форми 3 точки зору інвестора відноситься отримання в користування приватним партнером існуючого комунального (державного) майна, можливе залучення персоналу медичного закладу до проєкту ДПП, суб’єктність у відносинах 3 державою (НСЗУ) i приватними споживачами медичних послуг. Громада, нарешті, отримає якісні стоматологічні послуги i, після закінчення терміну договору - модернізований / відремонтований / побудований об’єкт медичної інфраструктури;

2) спільна діяльність. Грунтується на договорі про спільну діяльність [9]. Розподіл прав і обов'язків сторін за таким договором є досить складним, як i наступний облік результатів діяльності. Зрештою, комунальна або державна медична установа залишається суб’єктом (ліцензіатом), який надає медичні послуги й отримує за це гроші від держави або приватних осіб, маючи інвестора в якості партнера. Перевагою такої форми для інвестора $\epsilon$ обмежена 
відповідальність приватного партнера головним чином за внесення інвестицій в об’єкт ДПП (технічне переоснащення, ремонт, будівництво приміщень, сервісне обслуговування медичного обладнання і т.д.). Недоліками такої форми можна вважати законодавчу обмеженість в наданні платних медичних послуг i неможливість для інвестора укладення прямих договорів з НСЗУ.

3 огляду на викладе, досить перспективним напрямком інноваційного розвитку стоматологічної допомоги населенню в Україні $\epsilon$ створення стоматологічних центрів (СЦ) у складі університетських клінік на засадах ДПП, що передбачає ефективну взаємодію медичної науки, освіти та стоматологічної практики на базі стратегічного альянсу органів влади, університетських клінік та приватних інвесторів.

Створення таких СЦ є доцільним із метою розвитку клінічної та наукової діяльності, а також для розвитку якісної стоматологічної допомоги, орієнтованої на задоволення потреб пацієнтів [20]. Адже використання механізмів ДПП у системі університетських клінік дозволяє оптимізувати витрати бюджету таких клінік; забезпечити їх конкурентоспроможність, економічну стійкість, систематизувати надходження інвестицій, перейти на інноваційні технології та ін.

Передова практика розвинених країн світу дійсно засвідчує, що наразі саме ДПП $є$ ефективним інструментом вирішення ряду важливих соціальноекономічних завдань у сфері СДН: сприяє підвищенню якості обслуговування пацієнтів і доступності дорогих видів лікування, а також модернізації системи інформування, підвищенню рівня кваліфікації медичного персоналу тощо.

При цьому жодна держава світу не забезпечує повністю населення якісною та сучасною стоматологічною допомогою за рахунок коштів державного бюджету й не здатна виділяти необхідні кошти на сучасне стоматологічне обладнання, технології та матеріали для лікування (профілактики) стоматологічних захворювань у населення. На сьогодні один із ефективних організаційноекономічних і правових механізмів у системі інститутів некомерційних медичних організацій (державних, приватних), які не орієнтуються у своїй діяльності на отримання прибутку, реалізується у США. А от у Західній Свропі взято курс на скорочення втручання держави в економіку, припинення надмірного державного регулювання та передачу ряду повноважень кваліфікованим інститутам підприємницького співтовариства, а також залучення інвестицій для забезпечення населення стоматологічною допомогою на засадах ДПП.

Так, наприклад, специфіка європейської моделі медичного обслуговування в цілому полягає в тому, що повоєнному європейському капіталізму вдалося трансформувати свої політичні, економічні та соціальні інститути в напрямку створення соціально орієнтованого, економічно ефективного варіанта змішаної економіки. До основних особливостей європейської стоматології можна віднести 
доступність стоматологічних служб та якість послуг, інтеграцію стоматологічних i загальних служб охорони здоров'я, раціональну основу стоматологічного обслуговування, використання бригадного методу роботи у стоматологічних службах, високотехнологічне обладнання стоматологічного кабінету i його використання, проведення соціологічних досліджень та профілактики серед населення [21].

Таким чином удосконалення СДН у прогресивній міжнародній практиці розвивається по шляху: підтримки системи СДН з боку держави; наявності декількох джерел фінансування СДН; дотримання прав людини в системі охорони здоров’я загалом; відповідальності держави за стоматологічну допомогу соціально незахищеним верствам населення та ін. Тобто удосконалення системи управління СДН полягає, насамперед, в розумному поєднанні адміністративного $\mathrm{i}$ професійного управління в цій сфері.

Висновки. Резюмуючи вищевикладене можемо зробити висновки, що ДПП має стати невід’ємним елементом сучасної економіки нашої країни, адже ДПП дозволяє підвищити якісний рівень суспільних благ і сприяє формуванню державної політики, адекватної до сучасних умов соціально-економічного розвитку. Водночас ДПП $є$ ефективним інвестиційним інструментом для впровадження як у галузь охорони здоров’я загалом, так і у сферу стоматологічної допомоги населенню в тому числі, інноваційних практик лікування, навчання кадрів, технологічного оснащення клінік, поліпшення якості надання медичної /стоматологічної допомоги та в цілому може сприяти формуванню сучасних університетських клінік.

Перспективи подальших досліджень полягають у використанні отриманих результатів для обгрунтування й розробки базових механізмів ДПП у сфері стоматологічної допомоги населенню в Україні.

\section{Jimepamypa:}

1. Павленко О.В., Вахненко О.М. Шляхи реформування системи надання стоматологічної допомоги населенню України. Дискусія. Современная стоматология. 2013. № 2. С. 180-181.

2. Добагян Е.К. Факторы и современные тенденции развития ГЧП в здравоохранении на примере зарубежного опыта. Человеческий капитал и профессиональное образование. 2016. № 2. C. $75-78$.

3. Друкер П.О. О профессии менеджера/пер. с англ. М.: “Вильямс", 2008. 320 с.

4. Чопчик В. Державно-приватне партнерство - модель для реформування університетської клініки. Ukrainian scientific medical youth journal . 2019. Вип. 4 (112). С.47-53.

5. Петрова І.П. Поняття державно-приватного партнерства: оцінка зарубіжних i вітчизняних визначень. Вісник економічної науки Украӥни. 2014. № 3 (27). С. 88-99.

6. Practical guidance on good governance in public-private partnerships. Economic Commission for Europe; United Nations. New York - Geneva: UN. 2008. 114 p.

7. Guidelines for Successful Public-Private Partnerships European Commission Directorate- 
General Regional Policy. March 2003. 16 p.

8. Воробйова М.О. Особливості процедури прийняття рішення про здійснення проєктів державно-приватного партнерства. Вісник Київського наџіонального університету імені Тараса Шевченка. 2018. Вип. 1. С. 19-26.

9. Про державно-приватне партнерство : Закон України від 01 лип. 2010 р. № 2404- VI. URL: https://zakon.rada.gov.ua/go/2404-17 (дата звернення: 12.04.2021).

10. Сугак Т.М. Розвиток державно-приватного партнерства у сфері водопостачання в Україні: переваги та недоліки. Вісник Дніпропетровського університету. 2016. Т. 24. Вип. 10(1). С. 33-40.

11. Крутова А.С., Тарасова Т.О., Кащена. Н.Б. Проєкти державно-приватного партнерства: реалізація та аналіз ефективності. Економічний простір. 2019. № 141. С. 158-171.

12. Турчак Д.В. Механізми державно-приватного партнерства у сфері охорони здоров’я : дис. ... канд. держ.упр. : 25.00 .02 - механізми державного управління. Інститут підготовки кадрів державної служби зайнятості України, Київ, 2019. 240 с.

13. Методичні рекомендації для державних та комунальних закладів охорони здоров'я для працівників органів управління у сфері охорони здоров'я для впровадження проектів державно-приватного партнерства у сфері охорони здоров'я. 2018. URL: http://moz.gov.ua/uploads/1/7840-1234567890.pdf.

14. Про стоматологічну діяльність : проєкт Закону України від 31 трав. 2016 р. № 4736. URL : http://w1.c1.rada.gov.ua/pls/zweb2/webproc4_1?pf3511=59262.

15. Савчук О.В. Комплексне медико-соціальне обгрунтування реструктуризації муніципальної системи стоматологічної допомоги із залученням сучасних клінічних інноваційних технологій та менеджменту : автореф. дис. ... докт. медичних наук; спеціальність 14. 01. 22 - стоматологія 14. 02. 03. - соціальна медицина. Ужгород, 2019. 46 с.

16. Про державні фінансові гарантії медичного обслуговування населення : Закон України від 19 жовт. 2017 р. № 2168-VIII. URL : http: www.rada.gov.ua. (дата звернення: 07.04.2021).

17. Шевцов В. Мобільність як ключовий принцип надання стоматологічної допомоги в об’єднаних територіальних громадах. Державне управління та місцеве самоврядування. 2019. №3(42). С. 160-166.

18. Литвинова Л.О., Донік О.М., Артемчук Л.І. Реформування стоматологічної допомоги населенню України : проблеми сьогодення. Український стоматологічний альманах. 2020. № 2. C. 109-114.

19. Про концесію: Закон України від 03 жовт. 2019 p. № 155-IX. URL: https://zakon.rada.gov.ua/go/155-20 (дата звернення: 12.04.2021).

20. Чопчик В.Д. Інвестування в університетські клініки на основі механізму державноприватного партнерства. Вісник соціальної гігієни та організації охорони здоров'я Украӥни. 2019. Вип.3. С. 109-113.

21. Викторов В.Н., Козлова Н.Е., Денисова Т.Г. Развитие стоматологической службы за рубежом (обзор литературы). Здравоохранение. 2013. Вып. №3. С. 17-21.

\section{References:}

1. Pavlenko, O.V., \& Vakhnenko, O.M. (2013). Shliakhy reformuvannia systemy nadannia stomatolohichnoi dopomohy naselenniu Ukrainy. Dyskusiia [Ways to reform the system of providing dental care to the population of Ukraine. Discussion]. Sovremennaia stomatolohyia - Modern dentistry, 2, 180-181 [in Ukrainian].

2. Dobagyan, E. K. (2016). Faktory` i sovremenny`e tendenczii razvitiya GChP v 
zdravookhranenii na primere zarubezhnogo opy ta [Factors and current trends in the development of PPP in health care on the example of foreign experience]. Chelovecheskij kapital i professional noe obrazovanie - Human capital and professional education, 2, 75-78[in Russian].

3. Druker, P.O. (2008). O professii menedzhera [About the profession of manager]: M.: "Vil yams" [in Russian].

4. Chopchyk, V. (2019). Derzhavno-pryvatne partnerstvo - model dlia reformuvannia universytetskoi kliniky [Public-private partnership is a model for reforming the university clinic]. Ukrainian scientific medical youth journal, 4 (112), 47-53 [in Ukrainian].

5. Petrova, I.P. (2014). Poniattia derzhavno-pryvatnoho partnerstva: otsinka zarubizhnykh i vitchyznianykh vyznachen [The concept of public-private partnership: assessment of foreign and domestic definitions]. Visnyk ekonomichnoi nauky Ukrainy - Bulletin of Economic Science of Ukraine, 3 (27), 88-99 [in Ukrainian].

6. Practical guidance on good governance in public-private partnerships. Economic Commission for Europe; United Nations. New York - Geneva: UN. 2008. 114 p.

7. Guidelines for Successful Public-Private Partnerships. European Commission DirectorateGeneral Regional Policy. March 2003. 16 p.

8. Vorobiova, M.O. (2018). Osoblyvosti protsedury pryiniattia rishennia pro zdiisnennia proiektiv derzhavno-pryvatnoho partnerstva [Features of the decision-making procedure for the implementation of public-private partnership projects]. Visnyk Kyivskoho natsionalnoho universytetu imeni Tarasa Shevchenka - Bulletin of Taras Shevchenko National University of Kyiv, 1, 19-26 [in Ukrainian].

9. Zakon Ukrainy "Pro derzhavno-pryvatne partnerstvo" [Law of Ukraine "On Public-Private Partnership"]. (n.d.). zakon.rada.gov.ua. Retrieved from https://zakon.rada.gov.ua/go/2404-17 [in Ukrainian].

10. Suhak, T.M. (2016). Rozvytok derzhavno-pryvatnoho partnerstva u sferi vodopostachannia v Ukraini: perevahy ta nedoliky [Development of public-private partnership in the field of water supply in Ukraine: advantages and disadvantages]. Visnyk Dnipropetrovskoho universytetu - Bulletin of Dnipropetrovsk University, 10(1), 33-40 [in Ukrainian].

11. Krutova, A.S., Tarasova, T.O., \& Kashchena, N.B. (2019). Proiekty derzhavno-pryvatnoho partnerstva: realizatsiia ta analiz efektyvnosti [Public-private partnership projects: implementation and analysis of effectiveness]. Ekonomichnyi prostir-Economic space, 141, 158-171 [in Ukrainian].

12. Turchak, D.V. (2019). Mekhanizmy derzhavno-pryvatnoho partnerstva u sferi okhorony zdorovia [Public-private partnership mechanisms in the field of health care ].Candidate's thesis. Kyiv [in Ukrainian].

13. Metodychni rekomendatsii dlia derzhavnykh ta komunalnykh zakladiv okhorony zdorovia dlia pratsivnykiv orhaniv upravlinnia u sferi okhorony zdorovia dlia vprovadzhennia proektiv derzhavno-pryvatnoho partnerstva $\mathrm{u}$ sferi okhorony zdorovia [Methodical recommendations for state and municipal health care institutions for employees of public health authorities for the implementation of public-private partnership projects in the field of health care]. (2018). Retrieved from http://moz.gov.ua/uploads/1/7840-1234567890.pdf [in Ukrainian].

14. Proiekt Zakonu Ukrainy "Pro stomatolohichnu diialnist" [Draft Law of Ukraine "On Dental Activities"]. (n.d.). zakon.rada.gov.ua. Retrieved from http://w1.c1.rada.gov.ua/pls/zweb2/webproc4 _1?pf3511=59262 [in Ukrainian].

15. Savchuk, O.V. (2019). Kompleksne medyko-sotsialne obgruntuvannia restrukturyzatsii munitsypalnoi systemy stomatolohichnoi dopomohy iz zaluchenniam suchasnykh klinichnykh 
innovatsiinykh tekhnolohii ta menedzhmentu [Complex medico-social substantiation of restructuring of the municipal dental care system with additional using of the modern clinical innovative technologies and management]. Extended abstract of Doctor's thesis. Uzhhorod [in Ukrainian].

16. Zakon Ukrainy "Pro derzhavni finansovi harantii medychnoho obsluhovuvannia naselennia" [Law of Ukraine "On state financial guarantees of medical care"].(n.d.). zakon.rada.gov.ua. Retrieved from http: www.rada.gov.ua [in Ukrainian].

17. Shevtsov, V. (2019). Mobilnist yak kliuchovyi pryntsyp nadannia stomatolohichnoi dopomohy $\mathrm{v}$ obiednanykh terytorialnykh hromadakh [Mobility as a key principle in providing dental care in integrated communities]. Derzhavne upravlinnia ta mistseve samovriaduvannia - Public administration and local self-government, №3(42), 160-166 [in Ukrainian].

18. Lytvynova, L.O., Donik, O.M., \& Artemchuk, L.I. (2020). Reformuvannia stomatolohichnoi dopomohy naselenniu Ukrainy : problemy sohodennia [Reforming dental care for the population of Ukraine: current problems]. Ukrainskyi stomatolohichnyi almanakh - Ukrainian Dental Almanac, 2, 109-114 [in Ukrainian].

19. Zakon Ukrainy "Pro kontsesiiu" [Law of Ukraine "On Concession"]. (n.d.). zakon.rada.gov.ua. Retrieved from https://zakon.rada.gov.ua/go/155-20 [in Ukrainian].

20. Chopchyk, V.D. (2019). Investuvannia v universytetski kliniky na osnovi mekhanizmu derzhavno-pryvatnoho partnerstva [Investing in university clinics based on the mechanism of publicprivate partnership]. Visnyk sotsialnoi hihiieny ta orhanizatsii okhorony zdorovia Ukrainy - Bulletin of social hygiene and health care organization of Ukraine, 3, 109-113 [in Ukrainian].

21. Viktorov, V.N., Kozlova, \& N.E., Denisova, T.G. (2013). Razvitie stomatologicheskoj sluzhby`za rubezhom (obzor literatury`) [Development of dental service abroad (literature review) ]. Zdravookhranenie - Healthcare, 3, 17-21 [in Russian]. 